\title{
The Correlation between Students' Motivation and Their Speaking Achievement at English Department of Halu Oleo University
}

\author{
Wa Ode Fatimah \\ Halu Oleo University \\ wd.fatimah@gmail.com \\ Firdaus Sale \\ Halu Oleo University \\ firdaussale@gmail.com \\ Yulius Tandi Sapan \\ Halu Oleo University \\ Yulius_ts70@yahoo.com
}

\begin{abstract}
This research focused on the correlation between students' motivation and their speaking achievement. The research conducts in Halu Oleo University, English Department at academic year 2017/2018 that have pass Speaking III to see their motivation and speaking achievement. There are 36 students taken as sample. The data of the research collect through close-ended questionnaire adapted from Gardner (1985) who had developed the Attitude/Motivation Test Battery (AMTB) to get the data of students' motivation index (integrative motivation and instrumental motivation), especially in speaking III. To analyze the data, the researcher uses descriptive statistic to find out the students' speaking achievement and their motivations based on the five categories of; very good, good, moderate, low and failed. The researcher uses the SPSS 16 program as the statistical program to analyze the data. The finding of the research shows that students' speaking achievement was mostly categorized as a moderate category and students are moderate motivated in speaking English. The result of inferential statistical analysis show that the result of the Pearson correlation is valued as much as $r_{x y}=0,479$ (moderate correlation) with positive significant $0.03\left(r_{x y}<0.05\right)$. Based on the data, the researcher found that there is a significant correlation between students' motivation and their speaking achievement at English Department of Halu Oleo University. Motivation is an important factor that influenced students' achievement. Motivation is directly proportional to the score of students. The higher the students' motivation to speak, the higher their speaking score achieved.
\end{abstract}

Keywords: Motivation (integrative and instrumental, Speaking, Speaking achievement,

\section{Introduction}

Speaking is a language skill that has a process of communicating and telling an idea or message to the listener or the 
other person. Bowen (1985) stated that there are some aspects that mostly influence in speaking, such as: pronunciation, vocabulary, and grammar. It means that we must pay attention to the rules of speech so that we can avoid miscommunication between the speaker and the listener. So that, in speaking we must be able to master grammar, vocabulary and how we pronounce it (pronunciation) in order to avoid miscommunication. If in speaking one of these aspects is error, it can cause misunderstandings.

Speaking is an activity which gives someone an opportunity to practice a language in their everyday life. But some students are still unmotivated to speak and make conversation in English. In every class, several students are not having motivation to speak English. This makes the teacher or friends around him to extra-motivate them to encourage their willingness to talk in order that they can achieve their desired goals. However, there are some students who have very high motivation towards learning English language, and still unmotivated to speak English in front of their friends or lecturer. That makes some students have low grade in speaking subject.

The above facts indicate that there is a correlation between students' motivation and speaking achievement. Low motivation problems that often occur in students seems to motivate them not to show involvement in the learning process, especially in the process of speaking English. There are potential problems that make the students cannot inform their idea. Those are shyness, nervousness, feeling afraid of making mistakes; do not know how to pronounce certain words, lack of self-confidence and low level of motivation. Those factors too much become the reasons why the students of Halu Oleo University often get problems in speaking though they have to study English from elementary school until senior high school.

In line with the above matters, the researcher is interested in investigating the correlation between students' speaking achievement and their motivation. Thus, this current research aims at finding out the 
correlation between students' speaking achievement and students' motivation at English Department of Halu Oleo University. Therefore, this study is going to answer the research question: 'Is there any significant correlation between students' motivation and their speaking achievement at English Department students of Halu Oleo University? "

\section{Theoretical Framework}

Definition of Speaking

Speaking is a tool to communicate which can inform our idea or message to other people. Ur (1996) also state that speaking seems to be the most important skills of all the four skills (listening, speaking, reading and writing) because people who know a language are usually shown to as speakers of that language. Davies and Pearse (1998) said that the major goal of all English language teaching should be given learners the ability to use English effectively, accurately in communication.

\section{Motivation}

Gardner (1985) had identified motivation as one of the main factors affecting English language teaching. It means that, motivation is one of the main factors that make students interesting in speaking English. Motivation is defined as the effort to acquire the language because of the desire to do so and the satisfaction derived from it. Motivation has an important role in success and failure in learning a second language. According to Ryan \& Deci (2000), "to be motivated means to progress or to be in motion to do something". Merriam-Webster (1997) also defined motivation as the act or process of motivating; the condition of being motivated; a motivating force, stimulus, or influence; incentive; drive; something (such as a need or desire) that causes a person or student to act. Syafryadin (2013) also stated that high motivation became one of the factors which decided whether the students' speaking can be successful or not.

Relevant Study 
There are two previous researches which have relationship with this future research. First, Hasdairta (2016) concluded in his research on the Exploring the role of motivation and anxiety in students' English-speaking achievement at Halu Oleo University, that there was no correlation of motivation and anxiety on the students' speaking performance which is resulting on their speaking achievement. The big point from the result of the research was their motivation was coming from their big passion and a great effort to learn better and finally they created a better performance in speaking. It means that, motivation was the cause which makes students' good in speaking achievement.

Second, Wong Yin Mun (2011) his study was conducted and intended to find out which of the two motivations - whether instrumental motivation or integrative motivation has greater influence towards UTAR FAS third year Chinese Students in their second language learning process. The result of the research had indicated that the undergraduates were more likely to have a stronger instrumental motivation (1942 points) compared to integrative motivation (1778 points) in their second language learning process. As a whole, they learnt the second language (English language) due to certain academic and professional reasons; for instance, to pass an examination, or to apply for a well-paid job. 


\section{Research Methodology}

The design of this study was correlation design. It used two classes, namely class $A$ and $B$. The population of this research was all students at English Department of Halu Oleo University in academic year 2017/2018. The total of population was around 120 students. The samples of this study were class B (36 students). The instrument of this study was motivation questionnaire adapted from AMTB Gardner (1985) which consisted of 22 numbers of questions.

\section{Findings and Discussion}

Findings

Student's Motivation

Based on the result of the research, the students' motivation categorized into three levels, as showed in the following table:

\begin{tabular}{|l|l|l|l|}
\hline Categorization & Formula & Frequency & Percentage (\%) \\
\hline High & $(92.18 \geq X)$ & 5 & $13.8889 \%$ \\
\hline Moderate & $\begin{array}{l}(79.75 \leq X< \\
92.18)\end{array}$ & 25 & $69.4444 \%$ \\
\hline Low & $(X<79.75)$ & 6 & $16.6667 \%$ \\
\hline
\end{tabular}

The result showed that the mean of the motivation of the students was 99 , the standard deviation was 6.21742, the median is 86.5, the minimum score was 77 and 8 maximum one was 99. In addition, from the analysis of the data above, there were three categories of the students' motivation. The first category was the students with low motivation $(x<79.75)$. The students with low motivation there were six students that have a score under 79.75. The second category was the students with moderate motivation where there were 25 students that have score 79.75 until 92.18. Then, there were five students who have the high motivation $(x \geq 92.18)$. 
Students' Speaking Achievement

The distribution of students' speaking score in speaking III class is described below:

\begin{tabular}{|l|l|l|l|}
\hline Categorization & Score Interval & Frequency & Percentage\% \\
\hline Very good & $85-100$ & 3 & 8.333333 \\
\hline Good & $71-84$ & 12 & 33.33333 \\
\hline Moderate & $60-70$ & 16 & 44.44444 \\
\hline Low & $40-59$ & 5 & 13.88889 \\
\hline Very Low & $0-39$ & 0 & 0 \\
\hline Total & & 36 & 100 \\
\hline
\end{tabular}

Based on the above table, the students' speaking achievement belongs to low to a very good category; with the most dominant students' score were the moderate category. It is indicated by the mode or the highest frequencies of students' score distribution were in the moderate category.

The Correlation between students' motivation and speaking achievement.

Test of Normality

To determine whether the scores are distributed normally or not, the researcher used SPSS version 16 based on Shapiro-Wilk analysis as follow:

\begin{tabular}{|l|r|r|r|r|r|r|}
\hline \multirow{2}{*}{} & \multicolumn{3}{|l|}{ Kolmogrov-Smirnov } & \multicolumn{3}{l|}{ Shapiro-Wilk } \\
\cline { 2 - 8 } & Statistic & \multicolumn{1}{l|}{ Df } & \multicolumn{1}{l|}{ Sig. } & \multicolumn{1}{l|}{ Statistic } & \multicolumn{1}{l|}{ Df } & \multicolumn{1}{l|}{ Sig. } \\
\hline Achievement & .100 & 36 & .200 & .962 & 36 & .250 \\
\hline Motivation & .094 & 36 & .200 & .947 & 36 & .082 \\
\hline
\end{tabular}

By seeing the above table, we may conclude that both the data score of motivation and achievement are distributed normal, because significant score $>0.05$. Then, we may go so far to testing the correlation both the variable.

\section{Correlation Analysis}


In this research, the score of students' motivation and their speaking achievement was correlated by using Pearson correlation. . Further calculation of the coefficient correlation was computed by using SPSS 16. The detail result of analysis of correlation students' speaking achievement and students' motivation showed in the following table:

\begin{tabular}{|l|l|r|r|}
\hline \multicolumn{4}{|c|}{ Correlation } \\
\hline \multirow{3}{*}{ Motivation } & $\begin{array}{l}\text { Pearson } \\
\text { correlation }\end{array}$ & 1 & .479 \\
\cline { 2 - 4 } & Sig. (2-tailed) & & Achievement \\
\cline { 2 - 4 } & $\mathrm{N}$ & 36 & .003 \\
\hline Achievement & Pearson & .479 & 36 \\
\cline { 2 - 4 } & correlation & & 1 \\
\cline { 2 - 4 } & Sig. (2-tailed) & .003 & \\
\cline { 2 - 4 } & $\mathrm{N}$ & 36 & 36 \\
\hline
\end{tabular}

The result of inferential statistics analysis showed that the result of Pearson correlation by SPSS 16 is valued as much as $r_{x y}=0,479$ (moderate correlation) with positive significant $0.03\left(r_{x y}<0.05\right)$. Based on the data, the researcher found that there is significant correlation between students' motivation and their speaking achievement at English Department of Halu Oleo University.

\section{Discussion}

Gardner (1985) had identified motivation as one of the main factors affecting English language teaching. It means that, motivation is one of the main aspects that make students interesting in speaking English in order to achieve goals in EFL learning. The findings of this research showed that a high level of motivation in both high and low group in speaking III course. Based on the result of students' motivation in speaking III, the total score of instrumental motivation was higher than the total score of integrative motivation namely instrumental motivation (1824) > integrative 
motivation (1271). Same with Wong Yin Mun (2011), the result of the research had indicated that the undergraduates were more likely to have a stronger instrumental motivation (1942 points) compared to integrative motivation (1778 points) towards UTAR FAS the third year Chinese Students in their second language learning process. As a whole, they learn the second language (English language) due to certain academic and professional reasons; for instance, to pass an examination, or to apply for a well-paid job. We can conclude that the students' motivation at English Department student of Halu Oleo University were high motivation in instrumental motivation compared with integrative motivation. Students more interested to learn English because the students prefer to learn English for their future success rather than to be associated with English speaking countries or to be like native speakers. Students tend to learn English in getting a job, traveling abroad, good career, or they think they need English for further studies in their major. They didn't focus to learn English as the target language in order being able to speak foreign languages and experience an appreciation of different cultures.

The above findings indicate that most of the students were categorized as a moderate level of speaking since the average score was 69.79. It was supported by 16 students (44.44\%) have the moderate level in speaking. While only 3 students (8.33\%) were having very high and 12 students (33.33\%) having a good level. Then, 5 students (13.88\%) were having low speaking achievement.

The main concern of this study is investigating whether students' motivation and their speaking achievement are significantly correlated. The researcher then employed Pearson correlation coefficient to find out the correlation. To determine the correlation both the variables, the researcher was used Pearson product moment correlation and SPSS 16 in order to ease analyzed the data.

The result indicates that there is a significant correlation between students' motivation and their speaking achievement. The motivation of students with moderate level and moderate achievement are not 
different at statistically significance 0.479 is higher than 0.294 with the coefficient valued 0.479 which was categorized as moderate correlation. The results of the study indicated that there was a positive relationship between their achievement and motivation. If the students' motivation increases, the speaking value of students also increases. So motivation and achievement have a positive correlation. This might be due to the fact that the students who got a high-grade average in English courses tended to be interested in English learning. The students' achievement had an improving by their motivation. These significant results were in line with Yu-mei (2009), motivation is one of several important factors that may influence students' English achievement. These significant results were in line with Liu (2007). Therefore, this study showed that motivation of the students was positively correlated with their English achievement.

\section{Conclusion and Recommendation}

Based on the findings, the result of the descriptive and inferential statistic by using SPSS 16 and Pearson correlation, which show the significant is 0.03 and $r$-pearson correlation $=0.479$ ) categorized as moderate correlation. In addition, we can conclude that there is a significant correlation between students' motivation and their speaking achievement of English Department Students at Halu Oleo University. Furthermore, the hypothesis testing was found that value of rxy is higher than t-table. It means that $\mathrm{H}_{0}$ is rejected and $\mathrm{H}_{1}$ is accepted. It was caused by students' motivation (instrumental and integrative motivation) and their speaking achievement categorized at moderate category.

Since the findings show that motivation affects students' speaking achievement, but it is not too significant, namely categorized in moderate significant. The researcher recommends to the teacher or lecturer in order to enhance students' speaking score and students' motivation, the lecturer should increase students' integrative motivation, because students are more fixated on learning the target language to be useful for their 
work and career in the future, they did not focus on how they learn the target language so they can master the language themselves.

\section{References}

Bowen. J. D. (1985). Tesol Technique and Procedure. Heinle and Heinle Publisher: A Division of Wodsworth, Inc. Boston

Davies, P. \& Pearse, E. (1998). Success in English Teaching. . Oxford University Press

Gardner, R.C. (1985). Social psychology and second language learning: The role of attitudes and motivation. London : Edward Arnold Publishers.

Hasdairta. (2016). EXPLORING THE ROLE OF MOTIVATION AND ANXIETY IN STUDENTS' ENGLISH SPEAKING ACHIEVEMENT. Kendari: Universitas Halu Oleo.

Liu, M. (2007). Chinese Students' Motivation to Learn English at The Tertiary Level. $\quad$ Retrieved from: $\quad$ http://www.asian-efljournal.com/March $07 \mathrm{ml} . \mathrm{php}$

Merriam-Webster (1997). Merriam-Webster's Dictionary, Houghton-Mifflin.

Mun, W. Y. (2011). A STUDY OF INSTRUMENTAL AND INTEGRATIVE MOTIVATIONS AS FACTORS INFLUENCING UTAR THIRD-YEAR CHINESE UNDERGRADUATES IN LEARNING ESL. Faculty of Arts and Social Science: Tunku Abdul Rahman University.

Ryan, R. M. \& Deci, E. L. (2000). Self-determination theory and the facilitation of intrinsic motivation, social development, and wellbeing. American Psychologist, 55(1), 68-78. Doi: 10.1037/0003066X.55.1.68 
Syafryadin. 2013. The use of Talking Chips in Teaching Speaking. Unpublished Thesis. Universitas Pendidikan Indonesia.

Ur, P. (1996). A course in Language Teaching. Practice and Theory. Cambridge: Cambridge University Press.

Writer Information

\begin{tabular}{|l|l|l|}
\hline Name & $:$ & Wa Ode Fatimah \\
\hline Affiliation & $:$ & Universitas Halu Oleo \\
\hline Email & $:$ & wd.fatimah@gmail.com \\
\hline Phone Number & $:$ & 08534567655 \\
\hline
\end{tabular}

